\title{
Chapter 6 \\ New Vision of the Role of Land \\ Reclamation Systems in Nature Protection and Water Management
}

\author{
Wiesław Dembek
}

\begin{abstract}
The chapter is devoted to selected problems that appear between nature protection and some aspects of water management. Basic paradigms of nature protection and the reasons why they are not understood in society are presented. The role of land reclamation in natural environment is described with special attention to its positive aspects. Examples of conflicts between land reclamation and nature protection and chances of their solution are presented. The importance is analysed of small retention and broadly understood reclamation activities for flood control. Exemplary attempts are given of implementing some activities to hamper unproductive water outflow from reclamation networks to the Polish model of common agricultural policy.
\end{abstract}

Keywords Nature protection - Land reclamation - Flood control - Conflicts • Areas of cooperation

\subsection{Introduction, Aim of the Study}

The study is aimed at analysing selected problems that appear in the relations between nature protection and land reclamation. The contact zone between the two is a traditional area of conflicts and polemics. Therefore, it is worth thinking for a moment of the sense of the notion "nature protection" and of priorities associated with this type of activity. Nature protection is not a scientific discipline; it is rather a skill based on various fields and disciplines of knowledge. It is mainly based on ecology since it very often deals with maintaining proper relationships between the elements of natural environment which is the domain of that science. Most often reason of misunderstanding is forgetting that both nature protection and ecology are not guided by anthropocentric philosophy and tradition; hence, they do not treat

\footnotetext{
W. Dembek $(\bowtie)$

Institute of Technology and Life Sciences, Al. Hrabska 3, 05-090 Falenty, Poland

e-mail: w.dembek@itp.edu.pl

(C) The Author(s) 2015

S. Ignar and M. Grygoruk (eds.), Wetlands and Water Framework Directive,

GeoPlanet: Earth and Planetary Sciences, DOI 10.1007/978-3-319-13764-3_6
} 
humans as a privileged species. On the contrary, nature protection sees human activity as the main source of disturbance in the natural environment. It seems that this statement is hardly acceptable by man since we are inclined to believe in the superiority of human interests by our child-rearing, school education, religion and any disturbance of these beliefs raises conscious or subconscious protest. Irrespective of various definitions, nature protection in its practical aspect focuses on these elements of biodiversity (species, genes, ecosystems or landscapes) which are presently endangered. In practice, a common species seldom becomes the object of interest from representatives of nature protection. If, however, this species faces a threat, then it becomes the object of their activity, proportional to the scale of endangerment. So, the author does not see a greater interest in the protection of the rook in Poland, of the raven recently increasing in number or of poor fox blamed for posing a threat to many species. Instead, the object of concern is once common species which are now endangered like the partridge, the black grouse, the northern lapwing, wolf etc. It thus appears that man cannot be the object of interest of nature protection specialists since our species is not endangered, especially in the global scale. It also appears that sometimes objectionable thesis that "a frog is more important than man" is most justified since it reflects the sense of nature protection activity. All amphibians in our country are-and probably will be - on the list of protected species, many of them are threatened and so refusing the frog its priority would negate the message every nature "protector" is guided by.

Laborious explanation of the above-mentioned priorities of current nature protection should be a base of each programme of ecological education since our society is permanently fed with inconsistent information on this protection by various groups of interest. Meanwhile, the most important paradigm of currently understood nature protection is to prevent the domination of any of these groups whose interests may be contradictory and may lead to the preference or extermination of various species. For example, dead wood - an important condition of preserving biodiversity in forest ecosystem-is a source of threat for a forester because some xylobionts (organisms living in wood) may pose a deadly threat to tree stands. The hare craved by hunters is hated by orchard owners, as is the starling for which we otherwise hang nesting boxes in parks. Anglers are eager to stock Polish waters with carp —an alien and invasive species which replaces native benthic-feeding fish species. Hunters are happy to see the mouflon and the fallow deer in our forests-both alien to Polish fauna and competitive for the European red deer.

\subsection{Environmental Role of Land Reclamation}

There are no such land reclamations that would be favourable for nature in the wild. Though it now seems obvious, several years ago one could find slogans on positive role of land reclamation without explaining the environmental context. Nevertheless, one had to agree that there are no really natural places in Poland. This may be a 
basis for a hypothesis that land reclamations may play a positive environmental role providing the environment is transformed by human activity.

You have to remember that wildlife in Poland almost never feel the excess water. Even disastrous floods were mostly favourable or at least neutral to the natural environment. In most situations the increased amount of water is favourable for nature in agriculturally used areas. There are few situations when decreasing amount of water is beneficial in cultivated areas. This is because, historically, the introduction of crop species under Polish conditions required decreasing the soil moisture in habitats. Grasses from cereal group are the steppe species, "noble" meadow grasses are the species from dry ground habitats and tuber crops consist in part of species from the subtropical zone.

A plant dies of oxygen deficit in soil and not of water excess. It also dies of water deficit but not of the excess of oxygen. It means that the amount of oxygen in root zone is important during drainage and water availability for plant roots is important during irrigation. Most grass species significant as the source of fodder develop optimally at air content in the root zone in the range of 8-12\% per volume (Szuniewicz 1979). Such air content corresponds to ground water levels given in Table 6.1 understood as the distance between water table and land surface. Estimating these depths is an effect of laborious experimental studies of the generations of Polish meadow and soil specialists.

Data from Table 6.1 show that, for most grassland habitats in Poland, the optimum ground water level is ca. $0.5 \mathrm{~m}$ beneath the land surface. In the last decades, ground water in these habitats has declined in the middle of the growing season to one or more metre, which had a detrimental effect particularly for meadows situated on shallow non-peat soils.

To continue deliberations on stereotypical formulations which sometimes carry misleading contents, it is worth thinking of the notion of flood. According to traditional definition, flood is a transitory hydrological phenomenon consisting in the rise of river waters which, after exceeding bankfull level, causes the inundation of large areas - river valleys, near-shore or depression areas which leads to measureable social and material losses. Water rising is a high river water level which leads to overflow and flooding the river valley. The reasons of floods are of two kinds: either flood control facilities do not play their role or social and material goods are situated by man in a place exposed to flooding. Considering water rising

Table 6.1 Optimum and extreme for plant survival levels of ground water in soils for grasses grown on permanent lowland grasslands (Szuniewicz et al. 1992)

\begin{tabular}{l|l}
\hline Soil conditions & Optimum (and extreme) depths of ground water $[\mathrm{m}]$ \\
\hline Poorly decomposed peat & $0.80(0.35-1.10)$ \\
\hline Medium decomposed peat & $0.65(0.35-0.95)$ \\
\hline Medium and strongly decomposed peat & $0.55(0.30-0.85)$ \\
\hline Strongly decomposed peat & $0.35(0.25-0.60)$ \\
\hline Shallow non-peat soils & $0.35(0.25-0.50)$ \\
\hline
\end{tabular}


as a natural phenomenon desired from the natural point of view, one may conclude that rivers cause water rising while people cause floods. The fact that rivers or other kinds of waters in the environment are not the reason of floods has far-reaching consequences for the philosophy of flood control and the ways of increasing its effectiveness. Noteworthy, in the flood directive (Directive 2007/60/EC of the European Parliament and of the Council of 23 October 2007 on the assessment and management of flood risks) the question of losses was removed from the flood definition and transferred to the notion of flood risk.

\subsection{Land Reclamation and Flood Control from the Nature Protection Point of View}

Discussions on flood protection in Poland worsen when the losses caused by flood are tragic in their sizes reality. This favours seeing water management from the anticrisis standpoint and not as methodical, complex and long-term activities. In the atmosphere of disaster and associated emotions, one often forgets that common interests of nature protection, flood control and land reclamation manifest themselves in flood prevention and not during the action of emergency services. The issues of land reclamation and flood control are closely associated with each other. Floods are not generated in rivers but in the catchment basin, i.e., in areas with functioning reclamation systems. Flood control is facilitated by the increased catchment retentiveness and the increased retentiveness is facilitated by, i.a., appropriate reclamation.

Commonly used are the terms of large and small retention. Large retention means water reserve contained in large, artificial water reservoirs while small retention includes many elements (Mioduszewski 1999, 2009):

- surface water retention, in this number:

regulation of water outflow from ditches and canals;

regulation of water outflow from ponds and puddles;

utilisation of valley retention;

small water reservoirs - biologically controversial;

damming natural running waters - as above;

- retention of ground water:

holding water in reclamation ditches and canals;

regulation of water outflow from drainage networks;

phyto-reclamation, agri-reclamation;

limiting surface runoff;

increasing soil water capacity;

counter-erosion measures;

ponds and infiltration wells; 
- soil retention:

soil loosening;

increasing humus content;

liming;

proper agro-technical measures;

proper crop rotation-green fields the year round;

- landscape retention:

complex spatial set of arable lands, meadows, pastures, forests, streams and ponds;

cluster and lane thickets;

counter-erosion measures;

large area of wetlands.

Having in mind that the potential of small retention may be estimated at several billion $\mathrm{m}^{3}$ and the combined capacity of 10 largest retention reservoirs in Poland is 1.7 billion $\mathrm{m}^{3}$, one has to notice that applied notions have reversed meaning - the potential of "small retention" is much larger than that of "large retention" but the former is more difficult to control. In the above set of elements composing the socalled small retention surprisingly many fall within the scope of reclamation. Data presented in Table 6.1 show that periodically there is a huge retention reserve. Its size is such that elevation of ground water table in peat soil by $10 \mathrm{~cm}$ is equivalent to an increment of several hundred $\mathrm{m}^{3}$ of water per ha. Data presented in Table 6.2. evidence potential retentive role of reclamation systems.

The author of the above simulation attributed great importance to soil retention. Water lifting in the network of detailed reclamation ditches in grasslands andpractically not used-regulating the outflow from drainage networks are also of great importance. Though the simulation is of a theoretical character, it shows a potential of the so-called small retention. Below, there is another simulation of the same author pertaining to a real catchment of an area of $9.2 \mathrm{~km}^{2}$ (Fig. 6.1, Table 6.3).

Table 6.2 Potential possibilities of increasing catchment retentiveness through reclamation measures - an example of the upper Narew River catchment (Kowalewski 2003)

\begin{tabular}{l|l|c}
\hline Potential measure & Existing status, $\mathrm{mln}^{3}$ & Target status, $\mathrm{mln}^{3}$ \\
\hline Water lifting in streams and rivers & 1.89 & 3.14 \\
\hline Water lifting in reclamation canals & 0.16 & 0.26 \\
\hline $\begin{array}{l}\text { Regulating the outflow from the } \\
\text { valley reclamation objects }\end{array}$ & 0.75 & 2.72 \\
\hline $\begin{array}{l}\text { Water lifting in the network of } \\
\text { detailed reclamation ditches in grasslands }\end{array}$ & 20.84 & 41.69 \\
\hline $\begin{array}{l}\text { Regulating the outflow from drainage } \\
\text { networks in arable lands }\end{array}$ & 20.89 & 41.79 \\
\hline Small water reservoirs & 15.84 & 31.69 \\
\hline Soil retention & 12.76 & 51.40 \\
\hline Total & 73.12 & 172.70
\end{tabular}




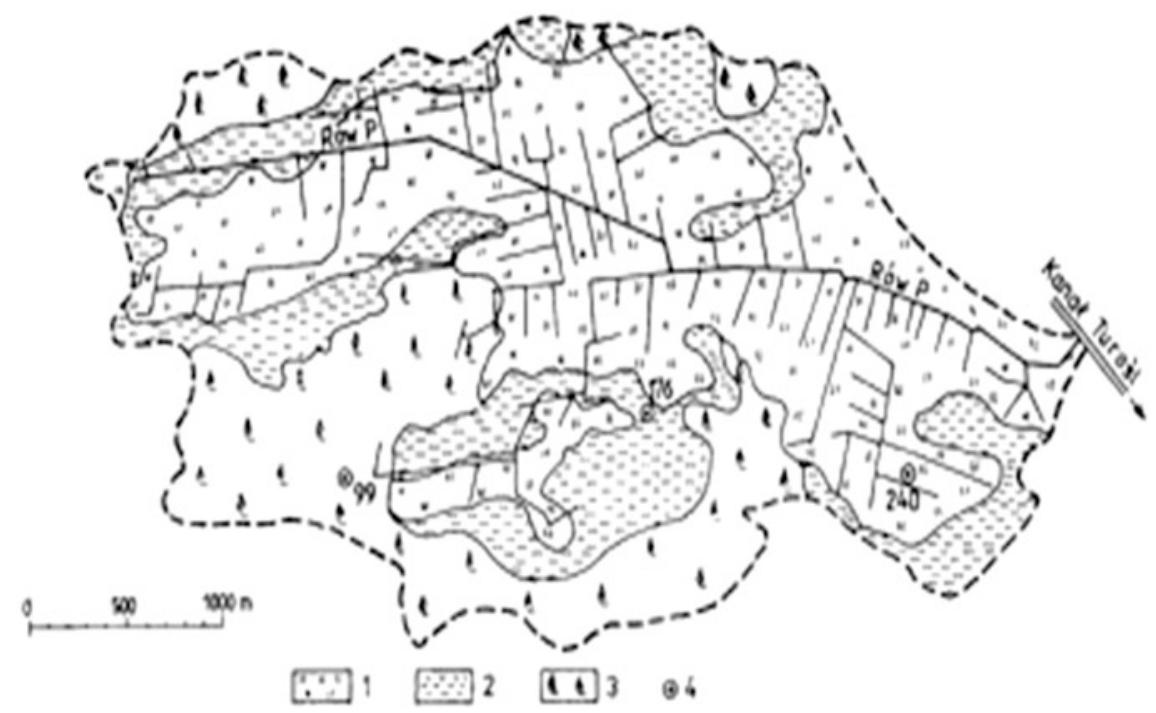

Fig. 6.1 A sketch of the $9.2 \mathrm{~km}^{2}$ catchment with the network of ditches functioning there (Kowalewski 2003); 1 Grasslands; 2 Arable land; 3 Forests; 4 Grid computing nodes

Table 6.3 Simulation of the retention effects at closed outflow from reclamation ditches in the catchment shown in Fig. 6.1 (Kowalewski 2003)

\begin{tabular}{l|l|l|l}
\hline \multicolumn{2}{l|}{ Simulated action } & $\begin{array}{l}\text { Hydrological } \\
\text { effects }\end{array}$ & $\begin{array}{l}\text { Increment } \\
\text { of retention }\end{array}$ \\
\hline $\begin{array}{l}\text { Variant } \\
\text { I }\end{array}$ & $\begin{array}{l}\text { A lack of water lifting in the reclama- } \\
\text { tion network-free outflow of water }\end{array}$ & $\begin{array}{l}\text { Ground water depth in } \\
\text { summer-ca. } 100 \mathrm{~cm}\end{array}$ & - \\
\hline Variant & $\begin{array}{l}\text { Closed outflow from the reclamation } \\
\text { network since April 1 }\end{array}$ & $\begin{array}{l}\text { Ground water depth in } \\
\text { summer-0 cm }\end{array}$ & $\begin{array}{l}\text { ca. } \\
386,000 \mathrm{~m}^{3}\end{array}$ \\
II
\end{tabular}

Completely closed outflow from ditches since April 1 results in the ground water level close to land surface, so it should not be applied in croplands. Such a variant may be considered only for lands abandoned by agriculture.

\subsection{Ecosystems that Might Be Significantly Affected by Land Reclamation}

Water-related ecosystems constitute $14 \%$ of the Poland's area; most of them are agricultural grounds used as meadows and pastures. There are 135 plant communities in grasslands out of 360 noted in Poland. From among 76 Polish natural habitats environmentally important for Europe and protected by the Habitat Directive (Dyrektywa 92/43/EWG...), 28 are associated with agricultural areas and 
Table 6.4 Natural habitats from the list of the Habitat Directive present in agricultural areas and their potential sensitivity to land reclamation

\begin{tabular}{l|l}
\hline Habitat & Sensitivity to reclamation \\
\hline Xeric sand calcareous grasslands & None \\
\hline Semi-natural dry grasslands & None \\
\hline $\begin{array}{l}\text { Species-rich mountain and lowland Nardus } \\
\text { grasslands }\end{array}$ & None \\
\hline Molinia meadows & $\begin{array}{l}\text { Very high-may exist in reclaimed } \\
\text { areas }\end{array}$ \\
\hline Cnidion venosae meadows & High—-must be flooded \\
\hline $\begin{array}{l}\text { Lowland and mountain extensively used fresh } \\
\text { meadows }\end{array}$ & $\begin{array}{l}\text { Low in lowlands; none in the } \\
\text { mountains }\end{array}$ \\
\hline Mountain hay meadows & None \\
\hline Continental salt meadows & $\begin{array}{l}\text { Very high—do not exist in reclaimed } \\
\text { areas }\end{array}$ \\
\hline Calcareous fens & $\begin{array}{l}\text { Very high—do not exist in reclaimed } \\
\text { areas }\end{array}$ \\
\hline Alkaline fens & $\begin{array}{l}\text { Very high—do not exist in reclaimed } \\
\text { areas }\end{array}$ \\
\hline
\end{tabular}

in that number 22 are water related. From among 75 bird species nesting in Poland and protected by the Bird Directive (Dyrektywa 2009/147/WE...), 34 are associated with rural areas including 25 species associated with meadows and pastures (Dembek et al. 2004). Lists of endangered and protected bird species associated with meadows and pastures of the country are much longer.

Selected natural habitats in agricultural areas which Poland is obliged to protect under the Habitat Directive and their sensitivity to reclamation are presented in Table 6.4. Table 6.4 shows that the sensitivity of natural habitats associated with agricultural areas and important for the European Union to activities typical for land reclamations is quite diverse. For some of them (sand calcareous grasslands, dry grasslands, mountain grasslands) reclamation measures have no sense. For otherssituated in river valleys - a change in water conditions caused by reclamations results in their elimination. Such habitats include calcareous and alkaline fens, salt meadows and flooded Cnidion venosae meadows.

Noteworthy, the share of mentioned habitats sensitive to reclamations in the total area of grasslands is negligible and of no economic importance. To sum up - under present natural and economic conditions there are no rational reasons to reclaim valuable non-forest ecosystems from the list of the Habitat Directive present in agricultural areas.

Highly sensitive to changes in water conditions are wetland habitats-agriculturally non-productive but often accompanying croplands-listed in the Habitat Directive:

- flooded muddy river banks;

- willow, poplar, alder and ash riparian forests; 
- oak-elm-ash riparian forests;

- coniferous and bog forests;

- transitional moors and quaking bogs.

These habitats are rather not endangered by reclamation, however, the protection of the first three habitats is associated with flood control problems described in Sects. 6.3 and 6.6.

\subsection{Possibilities of Improving Natural Habitat Through Land Reclamations}

Proper water management in habitats transformed by human activity is of great importance for environmental protection. Maintaining ground water levels at a depth optimum for meadow sward facilitates the protection of soil organic matter. This may be achieved by regulated outflow of water from reclamation ditches with the help of water lifting facilities (weirs or permanent sills).

Preservation of riparian rush vegetation, trees and shrubs may contribute to maintaining a mosaic character of the landscape, important for its biodiversity. In reclamation ditches this vegetation is usually removed since it interferes with mechanical conservation works. A lack of this type of vegetation means nonexistence of buffer zones being a filter for dissolved nutrients runoff from surrounding croplands, disappearance of bird sanctuaries for waterfowl and singing birds and finally the overheating of water and its decreased aeration. Radical mowing of bottom plants and de-silting is unfavourable from the nature protection viewpoint. Apart from the disappearance of aquatic and wetland plants and of benthic fauna, a stream devoid of vegetation loses its water purification properties.

Of fundamental importance for biodiversity is to provide an unobstructed flow in streams. Water lifting facilities desired in regulated or artificial streams pose a risk for the role streams play as ecological corridors. The equipment of larger dams with effective fish ladders and proper shaping of permanent sills is important in this aspect.

The question is, whether the abandonment—overgrowing by plants and siltation - of reclamation ditches is favourable from the nature protection viewpoint? Obviously yes, providing it is not associated with the abandonment of adjacent grasslands and when ditches are not equipped with water lifting facilities. Moreover, a lack of such facilities results in accelerated water outflow and increased flood risk.

It is worth mentioning of the importance of properly performed reclamation for the mitigation of climate changes. According to approximate calculations, the intensity of $\mathrm{CO}_{2}$ release from meadows on peatlands dried in uncontrolled way is by $22 \%$ larger than from irrigated meadows. Maintaining ground water levels at depths given in Table 6.1 would decrease $\mathrm{CO}_{2}$ emission to the atmosphere by ca. 17,000 tons a day in in the scale of Poland (Czaplak and Dembek 2000). 


\subsection{Conflicts}

It is unavoidable that some priorities of nature protection may come into conflict with the priorities of land reclamations performed for productive purposes. Nevertheless, the author observes proceeding - at least theoretical-concurrence of interests. Definite conflict may arise in the situation of making new reclamations in river valleys. The author passes over the question of actions in rivers which are out of the scope of this paper. Table 6.5 presents examples of such conflicts.

Best explained problem is the so far traditional source of conflicts mentioned in point 1: drainage. As demonstrated in this paper, water lifting in reclamation systems is the vital interest of nature protection, agriculture and flood control. It allows for utilising large retention resources shown in examples from Tables 6.2 and 6.3. The problem of disruption of continuity of aquatic ecological corridors by dams has been solved long ago. Of course, fish ladders and properly constructed sills would never achieve $100 \%$ efficiency. Nevertheless, ecological benefits from hampering water outflow from regulated streams may in many cases coincide with productive aspects. The problem described in point 3 of Table 6.4 has recently swollen in association with flood risk. As found by practitioners in flood control, trees and shrubs in flood terrace significantly reduce the hydraulic cross-section and influence increase the water level. Hence, a demand for cutting such plants. A need for an individual approach to such problems should be strongly recommended: protection of urban/agricultural areas and valuable habitats, which would not be present if dykes and valley between them were properly maintained. Different solutions are possible, but proper analysis necessary. Also if we want to cease useless quarrels

Table 6.5 Conflicts among land reclamations, flood control and nature protection and possibilities of their solution-examples

\begin{tabular}{l|l|l}
\hline Conflict & Reason & Chance of consensus \\
\hline Drainage & $\begin{array}{l}\text { Drainage causing soil } \\
\text { degradation and a loss } \\
\text { of biodiversity }\end{array}$ & $\begin{array}{l}\text { Possible: water lifting in "non-pro- } \\
\text { ductive" reaches by permanent sills } \\
\text { water lifting in productive reaches } \\
\text { by weirs }\end{array}$ \\
\hline $\begin{array}{l}\text { Hydrotechnical built-up of } \\
\text { streams }\end{array}$ & $\begin{array}{l}\text { Breaking continuity of } \\
\text { aquatic ecological } \\
\text { corridors }\end{array}$ & $\begin{array}{l}\text { Possible: fish ladders by dams } \\
\text { appropriately profiled tops of sills }\end{array}$ \\
\hline $\begin{array}{l}\text { Shrubs and trees between } \\
\text { embankments }\end{array}$ & $\begin{array}{l}\text { Water lifting during } \\
\text { floods }\end{array}$ & $\begin{array}{l}\text { Possible: in not protected habitats by } \\
\text { proper protection of areas outside the } \\
\text { embankment }\end{array}$ \\
\hline $\begin{array}{l}\text { Limitations associated } \\
\text { with nature protection near } \\
\text { flood embankments }\end{array}$ & $\begin{array}{l}\text { Impossible renovation } \\
\text { works }\end{array}$ & $\begin{array}{l}\text { Possible: depends on the endanger- } \\
\text { ment level (rarity) of habitats or } \\
\text { species }\end{array}$ \\
\hline Beaver & $\begin{array}{l}\text { Inundation of crop- } \\
\text { lands perforation of } \\
\text { flood embankments }\end{array}$ & $\begin{array}{l}\text { Possible though hardly achievable: } \\
\text { costly spillways in dams costly pro- } \\
\text { tection of flood embankments per- } \\
\text { mission for population reduction }\end{array}$ \\
\hline
\end{tabular}


with the use of stereotypes and slogans. The problem is that trees and shrubs may form valuable plant communities defined in the Habitat Directive as willow, poplar, alder and ash riparian forests. The presence of legally protected natural habitats enforces the protection of areas endangered by flood risk through adequate construction and conservation of flood embankments to avoid such dilemma. Probably in some cases such areas may be overgrown by unidentified shrub communities as a consequence of secondary succession on abandoned grasslands. Removing this vegetation is desired from the point of view of both biodiversity protection and flood control. Limitations associated with nature protection near flood embankments may-in the opinion of flood control specialists - cause problems with renovation of flood embankments. Postulated withdrawing from habitat and species protection in such places seems worth considering. Each case should, however, be analysed separately in view of the size of flood risk and the value of protected elements of the natural environment. In the case of species and habitats of least concern, blocking the possibility of renovation of flood embankments and exposing to costly flood risks seem absurd. A unique in the country and European scale sanctuary of protected species may, however, happen (probably exceptionally) to occur near flood embankments. In such case, considering the construction of an alternative embankment seems reasonable.

The problem of beavers' activity has recently been a constant element of discussions on the efficiency of flood control. The author is not a zoologist and cannot express his opinion in that matter. Knowledge of various source materials allows for a conclusion that problem with beavers appears only during floods. Apart from high water period, beavers do not inhabit flood embankments since there is no necessary water there. During rapid water rising, beavers are enforced to leave their lodges and search for dry land. The first such place is the flood embankment. Under threat, beaver is able to make a lodge there in a short period of time. Noteworthy, during extreme spring floods beavers suffer the greatest population losses among large mammal species since young beavers cannot swim. Moreover, there are no reliable data on beavers' contribution to water leaking through embankments in comparison with other reasons like too low height of embankments, a lack of their conservation or technical defects.

\subsection{Examples of Attempts Undertaken to Support Farmers in Hampering Water Outflow from Reclamation Systems}

The importance of water retention in reclamation systems to protect biodiversity and to control floods, not colliding with agricultural productive interests, was raised many times in documents know by the author. Beneath there are three examples of these documents. 
In the document of the Ministry of Environment (Środowiska 2005): "Strategy of wetland protection in Poland with the action plan" for the years 2006-2013 there is a statement: "\%.../Uninterrupted water outflow from reclaimed river valleys caused by a lack of water lifting facilities in drainage ditches is unfavourable in the country scale. It means that most hydrogenic sites in the country are aimlessly drained the year round. Properly organised limitation of water outflow from reclamation networks is realised only sporadically. Meanwhile, properly regulated outflow may support the existence of biocoenotically rich wet meadows - now very rare in the country. Application of scientific principles of water management in river valleys including the principle of retaining post-winter waters to irrigate soil in spring period during intensive plant growth and the principle of maximum accumulation of scarce water resources in summer are commonly neglected /.../".

The document articulates the need of development of wetland protection methods with the operational targets:

- counteracting the unproductive outflow of water from reclaimed habitats,

- dissemination of farming methods in conditions of high soil moisture.

The State Council of Nature Protection in its standpoint on the project: "Programme for the development of rural areas in the years 2007-2013" of May 10 2006 stated that: "/.../ It would be reasonable to orient activities: "Management of agricultural water resources" in a way to create financial preferences for retaining water in reclamation systems through irrigation and regulated outflow. This would have a great importance not only for production but also for water retention and flood control. Extremely important is the variant of micro-retention listed in the activity "Non-productive investments" of the Programme for the Development of Rural Areas /... /". The variant would be of great significance for nature and education. A possibility of installation by farmers small sills on ditches may result in unprecedented breakdown in the system of water management in detailed reclamation networks where farmers were so far mere supplicants, which was ineffective and conserved claiming attitudes."

On August 7, 2006, the Director of the Institute for Land Reclamation and Grassland Farming (now the Institute of Technology and Life Sciences) sent a letter to the Minister of Agriculture and Rural Development: "/.../ Considering the necessity of limiting agricultural losses caused by more and more frequent droughts and floods and the need of preserving natural values of rural areas I submit a request to include actions aimed at improving water balance to the Programme for the Development of Rural Areas for the years 2007-2013.

Agriculture is a branch of economy most exposed to losses due to water deficit or excess. Meanwhile, the course of atmospheric phenomena observed recently and predictions of many climatologists clearly indicate that extreme phenomena resulting in droughts and floods will be more and more frequent. There are justified fears that water deficit in particular will become a barrier limiting the development of country agriculture. In view of the above facts it is indispensable to undertake, as fast as possible, actions in order to improve the structure of water balance in small catchments through increasing retention capacity of agricultural landscape. The 
actions should primarily include the creation of "micro-retention" through hampering rapid water outflow from draining reclamation systems and the construction of small water reservoirs. Proposed actions will mitigate economic consequences of droughts and limit disastrous floods and hence will improve the economic status of farms. They will be also an important element of sustainable development of rural areas and of protection of their biodiversity. Moreover, they will form a basis for implementing the Water Framework Directive, Habitat and Bird Directives, which are the fundamentals of creating Natura 2000 areas. Water lifting in ditches and small streams and the construction of small water reservoirs will bring both economic and natural benefits. In many cases the development of micro-retention will need some limitations in agricultural production, e.g., due to flooding or excessive soil moisture in lower situated areas. Therefore, the accomplishment of the programme of water balance improvement requires financial support for farmers who undertake agri-environmental activities both during investment and exploitation phases. Due to benefits for the natural environment and agriculture, the activities aimed at increasing water retention should be considered in the Programme for the Development of Rural Areas for the years 2007-2013. Studies and analyses performed in our Institute clearly indicate that small investments to increase water resources commonly applied in farms will bring measurable benefits to farmers and the natural environment /... ${ }^{\prime}$.

Examples cited above indicate that there is a significant coincidence of priorities in the questions of nature protection and land reclamation. The priorities-during calm and objective discussion — should be used and bring synergistic effects.

\subsection{Conclusions}

1. For the necessity of equipment of reclamation ditches with water lifting facilities the standpoint of nature protection is essentially the same as postulates of land reclamation.

2. Increasing catchment retentiveness is extremely important for nature protection; being a task for land reclamation it is identical with the needs of modern understanding of flood control.

3. Drainage systems in arable lands have no significance for the protection of valuable natural habitats; important is, however, the retention of water flowing out of drains.

4. Floods and high levels of ground water in river valleys are, as a rule, very favourable for biodiversity.

5. Vegetation of managed meadows in Poland may exist in summer at water levels much higher than those observed in the last decades in the country.

Open Access This chapter is distributed under the terms of the Creative Commons Attribution Noncommercial License, which permits any noncommercial use, distribution, and reproduction in any medium, provided the original author(s) and source are credited. 


\section{References}

Czaplak I, Dembek W, (2000) Torfowiska Polski jako źródło emisji dwutlenku węgla (Poland's peatlands as a source of $\mathrm{CO}_{2}$ emission). In: Rolnictwo polskie i ochrona jakości wody. Zeszyty edukacyjne, Wydawnictwo IMUZ, Falenty

Dembek W, Dobrzyńska N, Liro A (2004) Problemy zachowania różnorodności biologicznej na obszarach wiejskich w kontekście zmian wspólnej polityki rolnej. (Problems of biodiversity preservation in rural regions), Woda-Środowisko-Obszary Wiejskie. Rozprawy naukowe i monografie, $\mathrm{Nr} 11$

Dyrektywa 2007/60/WE Parlamentu Europejskiego i Rady z dn. 23 października 2007 r. w sprawie oceny ryzyka powodziowego i zarządzania nim. Dz. Urz. U.E. L 288/27

Dyrektywa 2009/147/WE Parlamentu Europejskiego i Rady z dnia 30 listopada 2009 r. w sprawie ochrony dzikiego ptactwa. Dz. Urz. UE L020

Dyrektywa 92/43/EWG z dnia 21 maja 1992 w sprawie ochrony siedlisk przyrodniczych oraz dzikiej fauny i flory. Dz. Urz. UE L 206

Kowalewski Z (2003) Wpływ retencjonowania wód powierzchniowych na bilans wodny małych zlewni rolniczych (Effect of surface water retention on water balance of small agricultural catchments). Woda-Środowisko-Obszary Wiejskie. Rozprawy naukowe i monografie N 6. Wydawnictwo IMUZ Falenty

Mioduszewski W (1999) Ochrona i kształtowanie zasobów wodnych w krajobrazie rolniczym (Protection and shaping of water resources in agricultural landscape). Wydawnictwo IMUZ Falenty

Mioduszewski W. (2009) Retencjonowanie wód na obszarach wiejskich (water retentioning in rural areas). In: Mioduszewski W, Dembek W (eds) Woda na obszarach wiejskich. Ministerstwo Rolnictwa i Rozwoju Wsi, IMUZ Falenty

Środowiska M (2005) Strategia ochrony obszarów wodno-błotnych w Polsce wraz z planem działań (na lata 2006-2013)

Szuniewicz J (1979) Charakterystyka kompleksów wilgotnościowo-glebowych pod kątem parametrów systemu melioracyjnego (Soil moisture complex characterization and melioration system parameters). In: Okruszko H (ed) Kompleksy wilgotnościowo-glebowe w siedliskach hydrogenicznych i ich interpretacja przy projektowaniu melioracji i zagospodarowania. Biblioteczka Wiadomości IMUZ. Nr 58 s. 29-50

Szuniewicz J, Churska Cz, Churski T, (1992) Potencjalne hydrogeniczne siedliska wilgotnościowe i ich zróżnicowanie pod względem dyspozycyjnych zapasów wody użytecznej (Potential hydrogenic moisture habitats and their differentiation in terms of useful water). In: Hydrogeniczne siedliska wilgotnościowe. Biblioteczka Wiadomości IMUZ Nr 79 